\title{
Ruta Graveolens, Peganum Harmala and Citrullus Colocynthis Methanolic Extracts Have in Vitro Protoscolocidal Effects and Act Against Bacteria Isolated From Echinococcal Hydatid Cyst Fliud
}

\author{
Yaseen T. Al Qaisi \\ Mutah University

\section{Sawsan A. Oran \\ UJ: The University of Jordan \\ Amjad A. Al Tarawneh \\ Mutah University \\ Haitham Qaralleh \\ Mutah University \\ Talal S. Al-Qaisi \\ Al-Ahliyya Amman University \\ Husni S. Farah \\ Al-Ahliyya Amman University}

Khaled Khleifat ( $\nabla$ alkh_kha@hotmail.com )

Al-Ahliyya Amman University https://orcid.org/0000-0002-0216-3175

\section{Research Article}

Keywords: Echinococcosis, hydatid cyst, antibacterial, Ruta graveolens, Peganum harmala aerial parts, Citrullus colocynthis

Posted Date: March 1st, 2022

DOl: https://doi.org/10.21203/rs.3.rs-1388080/v1

License: (9) (i) This work is licensed under a Creative Commons Attribution 4.0 International License. Read Full License 


\section{Abstract}

Echinococcosis is a common and endemic disease that affects both humans and animals. In this study, the in vitro activities of methanolic extracts of Ruta graveolens, Peganum harmala aerial parts, and Citrullus colocynthis seeds against protoscolosis and isolated bacterial strains from hydatid cysts were assessed using disc diffusion methos and Minimum Inhibitory Concentration (MIC). The chemical composition of aerial sections of $R$. graveolensand $P$. harmala, as well as methanolic extracts of $C$. colocynthis seeds, was studied using LC-MS. These plants produced a total of 26, 31, and 23 chemicals, respectively. The bacteria listed below were isolated from hydatid cyst fluid collected from a variety of sick locations, including the lung and liver. Micrococcus spp., E. coli, Klebsiella oxytoca, Enterobacter aerogenes, Enterobacter amnigenus, Pseudomonas aeruginosa, Staphylococcus xylosus, and Achromobacter xylosoxidans are among the bacteria that have been identified. The most effective extract was $R$. graveolens, followed by $P$. harmala and $C$. colocynthis, according to the results of antibacterial activity using the disc diffusion method. $R$. graveolens extract had the lowest MIC values (less than $2 \mathrm{mg} / \mathrm{mL}$ ) against all microorganisms tested. This shows that the $R$. graveolens extract has additional properties, such as the ability to be both scolocidal and bactericidal. Because these bacteria are among the most prevalent pathogenic bacteria that increase the risk of secondary infection during hydatid cysts, the results of inhibitory zones and MICs of the $R$. graveolens methanol extract are considered highly promising.

\section{Introduction}

Cystic Echinococcosis (CE), is a parasitic disease that occurs in all mammals but mainly sheep and cattle. It also occurs in humans, caused by the larval stage of the tapeworm genus Echinococcus (Ali et al. 2012; Malekifard and Keramati 2018). Echinococcosis is a common and endemic health problem in humans and animals in most of the Mediterranean basin, including Jordan (Nasrieh et al. 2003). Canines serve as definitive hosts for the parasite, whereas herbivores serve as intermediate hosts for the hydatid cyst. After excretion by the definitive host, infection occurred due to intake of food or water contaminated with Echinococcus spp. eggs.(Hijjawi et al. 2018).

The fertile hydatid cysts are typically filled with a clear fluid contains protoscolices which is mostly bacteriologically sterile. Sometimes, liver and lung hydatid cysts can be infected with bacteria. Outside-released protoscolices have the ability to differentiate into secondary hydatid cysts in viscera. Cystic differentiation of protoscolices can probably be triggered by altered physiological conditions, such as bacterial diffusion into the cyst fluid causes the concerted effort between parasites and bacteria that cause some human and animal pathologies (Aitken et. 1978). According to Boes and Helwigh (Boes and Helwigh 2000), there are two types of synergy between parasites and bacteria: first, indirect synergy, that causes an increase in the pathogenic effects of the bacteria and makes the host susceptible to the bacterial disease, especially when the bacteria and parasites occur in the same tissue or organ; and secondly, a direct synergy that occurs when bacteria transported into the host by the parasite after invading stages of the parasite present in the environment (Ziino et al. 2009).

In animals, the synergy between CE and bacteria results in significant economic losses due to decreased meat, wool, and milk production, as well as the condemnation of infected organs (Jahed et al. 2013), whereas in people, the economic issues are due to the amplified costs of therapy and surgery (Ahmed et al. 2021). Antibiotics, whether synthetic or natural, are important biochemicals produced by living organisms and widely employed in medical use. In spite of producing a large number of new antibiotics by the pharmaceutical industries within the last three decades, microbial resistance to these drugs has increased as well (Al-Asoufi et al. 2017; dos Santos et al. 2001).

Uncontrolled use of commercial drugs by either patients or prescriptions that are made without susceptibility tests increases the resistance of bacteria and parasites (De Queiroz et al. 2014; Friedman et al. 2002). Therefore, more attention needs to be paid to increase the interest in plant extracts as antibacterial and antiparasitic agents.

Plant-based products are thought to account for $30 \%$ of all medicine sales worldwide. Jordan's check list of medicinal plants include 2552 flowering plant species, 363 of them are medicinal plants (Oran and Al-Eisawi 1998; Oran 2014), giving scientists encouragement to study and investigate their biological activities. The plant $R$. graveolens belongs to the family Rutaceae and 
is commonly known as Rue (Oran 2014). It is a herbaceous perennial that was originally native to the Mediterranean region (Asgarpanah \& Khoshkam, 2012). In Jordan, the plant $R$. graveolensis used as a spice (Hauajeh) (Oran and Al-Eisawi 1998). In folk medicine, it is used as an aphrodisiac and fertility-promoting agent (Asgarpanah and Khoshkam 2012), and is used to treat several diseases, including parasitic infections, inflammation, ulcers, hypotension, reproductive disorders, menstrual problems, and wounds. R. graveolens has anticancer and schistosomicidal activity (Amabye 2015; Asgarpanah and Khoshkam 2012; Carvalho et al. 2019; De Queiroz et al. 2014; Pathak et al. 2003). The $R$. graveolens extracts and essential oil showed good antibacterial and antifungal properties (Al-Shuneigat et al. 2015; Amabye 2015). According to Nabaei et al. (2014), no toxic effect was reported using different doses of hydro-alcoholic extract of $R$. graveolens on the histopathology of the liver. The plant $P$. harmala. is commonly known as Syrian Rue and has the Arabic names of Harmal and Harjal (Oran and Al-Eisawi 1998). It belongs to the family Zygophyllaceae, and is widely used in folk medicine. P. harmala alkaloids are used as anti-parasidal, antifungal, antibacterial, insecticidal, anti-leishmanial effects and anticancer by exhibiting a cytotoxic effect on leukemia cell lines.(Mamedov et al. 2018; Moazeni et al. 2014; Moazeni et al.2017; Moloudizargari et al 2013; Niroumand et al. 2015; Rezaee and Hajighasemi 2019; Sohrabi et al. 2018; Wink 2012).

Citrullus colocynthis belongs to the family of Cucurbitaceae (Oran and Al-Eisawi 1998). It is distinguished by the occurrence of many constituents such as flavonoids, alkaloids, carbohydrates, tannins, gums, and mucilage. $C$. colocynthis has been used in traditional medicine as anticancer, antibacterial, insecticidal, anti-diabetic and antiparasitic including Leishmania, Plasmodium and Haemonchus contortus (Ahmed et al. 2019; Dhakad et al. 2017; Uma and Sekar 2014).

The goal of this study was to find out how common bacterial infection is in hydatid cysts and to identify the most common bacteria species found in hydatid fluid. In addition, the effects of methanolic extracts of $P$. harmala aerial parts, $R$. graveolens, andseeds of $C$. colocynthis on the sustainability of bacterial strains and protoscolices isolated from hydatid cysts were studied in vitro.

\section{Materials And Methods}

\section{Microbial analysis for cyst fluid}

An entire of 3725 animals (sheep and goats) including 1675 native and 2050 imported have been collected between 1/8/2020 to $1 / 10 / 2020$, from slaughter houses in the area of Karak. The infected organs (liver or/and lung) were collected and transported to the laboratory within an hour of collection under refrigerated conditions. The infected organ surface was sterilized with $70 \%$ ethanol and washed with sterile distilled water. The hydatid fluid was aspirated by a sterile syringe, the protoscolices were isolated and the hydatid fluid cultured for isolation and identification of bacteria.

\section{Bacterial isolation and identification}

Initially the hydatid fluid was inoculated on three different types of media: blood agar for the bacterial isolation of aerobic and facultative anaerobic Gram-positive, Eosin Methylene Blue (EMB) agar and MacConkey agar for the isolation of Gram-negative bacteria. Then, the grown colonies were picked and inoculated on tryptone soy agar and nutrient agar to get pure culture.

To identify the bacterial isolates, colonies and cells characteristics were determined microscopically. The gram positive isolates were further characterized using standard biochemical tests including oxidase, DNase, catalase,phosphatase, coagulase and fermentation of mannitol, starch and sodium hippurate, pyrrolidonyl arylamidase (PYR) and Christie-Atkins, aesculin hydrolysis, Munch-Petersen (CAMP) tests, and novobiocin sensitivity. The gram negative isolates were further characterized using standard biochemical tests including motility, methyl red, urease, indole production, Voges-Proskauer, o-nitrophenyl- $\beta$ - $d$ galactopyranoside (ONPG) potassium cyanide $(\mathrm{KCN})$ and $\mathrm{H}_{2} \mathrm{~S}$ production, triple sugar iron agar (TSI), reactions of phenylalanine and lysine, lactose fermentation, ornithine decarboxylase tests. In addition, the identification was confirmed by using API 20E and API Staph diagnostic systems (Khleifat et al. 2008).

\section{Plant materials}


$R$. graveolens and $P$. harmala and $C$. colocynthis were collected in June, 2020. R. graveolens was collected from Irbid, northern of Jordan. P. harmala and C. colocynthis were collected from AL Karak, southern of Jordan. The plants were identified to species level by Prof. Sawsan Al Oran, Biology Department, Faculty of Science, Jordan University. The freshly gathered materials were washed, air-dried in the shade at room temperature and then ground into a reasonable powder using a mixer.

\section{Extraction}

A $100 \mathrm{~g}$ sample of both $R$. graveolensand $P$. harmala plants aerial parts, as well as $C$. colocynthis seeds, were steeped in 1000 $\mathrm{mL}$ methanol for 3 days at room temperature with continuous shaking. The solvent was extracted using a rotary evaporator at $45^{\circ} \mathrm{C}$ with reduced pressure after filtration. The extracts were kept in sealed glass vessels at $-20^{\circ} \mathrm{C}$.

\section{Determining the protoscolices' mortality}

The mortality of protoscolices was determined by measuring cell motility while staining with 0.1 percent aqueous eosin solution. Dead protoscolices stained with eosin and appear in reddish colour using a microscope, whereas alive protoscolices do not permeate the eosin and thus remain unchanged.(Al-Arabi et al. 2019; Smyth and Barrett 1980). The rate of mortality was considered by taking the number of dead protoscolices divided by the number of predicted headings.

Extracted protoscolices were kept in a sterile Roswell Park Memorial Institute (RPMI) 1640 medium provided with fetal bovine serum (10\%) under incubation of $37^{\circ} \mathrm{C}$. To control the contamination (Wang et al. 2015), penicillin (100 U/mL) and $100 \mu \mathrm{g} / \mathrm{mL}$ streptomycin sulphate were added to the medium (Malekifard and Keramati 2018; Monteiro et al. 2017). The impact of $P$. harmala, $R$. graveolens and seeds of $C$. colocynthis methanol extracts on the percentage of mortality of protoscolices in vitro was conducted. Protoscolices were treated with 10 to $40 \mathrm{mg} / \mathrm{ml}$ with being 10 as intervals of the three plantsby taking one milliliter of protoscolices suspension containing about $2 \times 10^{3}$ protoscolices $/ \mathrm{mL}$ in test tubes. The length of exposure periods was $1,3,6,12,18$, and 24 hours. To test the viability of protoscolices, $100 \mathrm{I}$ of pooled protoscolices were mixed with $100 \mathrm{I}$ of 0.1 percent eosin on a slide for 15 minutes; dead protoscolices stained red, while surviving protoscolices remained colorless, as observed under a compound microscope. Only samples with 100 percent viable protoscolices were used for the in vitro studies (Yones et al. 2011). For comparison, stock solution of albendazole (ABZ) (protoscolicidal agent available for treatment of human hydatid disease) prepared by dissolving $0.5 \mathrm{~g}$ in $1 \mathrm{~mL}$ of $30 \%$ DMSO the drug was filtered before using through a 0.22 $\mu \mathrm{m}$ filter. The efficacy of methanolic plants extract on the viability of protoscolices was compared with positive and negative control groups which received $20 \mathrm{mg} / \mathrm{mL} \mathrm{ABZ}$ and normal saline, respectively (Blanton et al. 1998). Experiments were carried out in triplicates. For obtaining images, digital camera type (Pro-MicroScan, 8M Pixels High-Speed) and light microscope (100x) model (OLYMPUS CX21FS1) were used.

\section{Dual staining with Acridine Orange- Ethidium Bromide (AO/EB)}

In seek to monitor the cellular and nuclear morphological changes, the protoscolices were treated with different concentrations of tested plants extracts and ABZ for $48 \mathrm{hrs}$, washed with PBS and dual stained with an equal volume of $A O(100 \mu \mathrm{g} / \mathrm{ml}) \mathrm{and}$ EB $(100 \mu \mathrm{g} / \mathrm{ml})$ for $2 \mathrm{~min}$ (Durgadevi et al. 2019). The preparation was examined using a fluorescent microscope, in which green-colored cells were indicative of viable protoscolices while those in red color are dead protoscolices.

\section{Antibacterial assay}

\section{Bacterial strains}

Methanolic extracts of aerial sections of $R$. graveolens and $P$. harmala plants, as well as seeds of $C$. colocynthis, were tested against eight bacterial species isolated from hydatid cysts. Two were Gram positive bacteria (Micrococcus spp. and $S$. $x y l o s u s$ ) and six were Gram negative bacteria (Micrococcus spp. and S. xylosus, P. aeruginosa, A. xylosoxidans, E. coli, E. amnigenus, E. aerogenes and $K$. oxytoca). In addition, strains of $S$. aureus, B. cereus, $B$. subtilis, $E$. coli, and $P$. aeruginosa with known ATCC identity were employed.

\section{Disc diffusion method}


The disc diffusion method was used to investigate the antibacterial activity of the various extracts (Alzoreky and Nakahara 2003). To obtain $2 \times 10^{6} \mathrm{CFU} / \mathrm{mL}$, broth cultures of the investigated bacteria were mixed with sterile nutritional agar that had been cooled to roughly $45-50^{\circ} \mathrm{C}$. After that, the inoculated agar was put onto sterile petri plates and left to harden for $45-60$ minutes. Then, under aseptic conditions, a disc containing $1 \mathrm{mg}, 2 \mathrm{mg}$ of plant extracts, $10 \%$ DMSO (negative control), or Tetracycline (positive control) was deposited on the surface of the agar plate. The growth inhibitory action was measured by measuring the diameter of the clear zone around the disc with a ruler after 24 hours at $37^{\circ} \mathrm{C}$ (Khleifat et al. 2006; Romero et al. 2005). Triplicates of each sample were evaluated.

\section{Minimum Inhibitory Concentration (MIC)}

Plant extracts' minimum inhibitory concentration (MIC) against bacterial growth was determined. A bacterial inoculum of $2 \times 10^{6} \mathrm{CFU} / \mathrm{mL}$ was inoculated into tubes containing a serial dilution of plant extract $(0-2 \mathrm{mg} / \mathrm{mL})$ in $5 \mathrm{~mL}$ Muller-Hinton broth. The MIC was calculated as the lowest concentration of extracts that inhibited observable bacterial growth (Khleifat et al. 2010; Patel et al. 2011).

\section{Liquid Chromatography-Mass Spectrometry (LC-MS).}

At a flow rate of $0.5 \mathrm{ml} / \mathrm{min}$, HPLC separation was performed with the mobile phase containing solvents $A$ and $B$ in gradient, where $A$ was 0.1 percent $(v / v)$ formic acid in water and $B$ was 0.1 percent $(v / v)$ formic acid in acetonitrile, for the following gradient: 5 percent B for 5 minutes, 5-100 percent B in 15 minutes, and 100 percent for 5 minutes. The Agilent Zorbax Eclipse XDB-C18 column was used $(2.1 \times 150 \mathrm{~mm} \times 3.5 \mathrm{um})$. The sample injection volume was $1 \mathrm{I}(18 \mathrm{mg} / \mathrm{mL}$ in methanol) and the oven temperature was $25^{\circ} \mathrm{C}$. The eluent was scanned from 100 to $1000 \mathrm{~m} / \mathrm{z}$ and secondary scan from 50 to $100 \mathrm{~m} / \mathrm{z}$ MRM modeusing a Shimadzu LC-MS 8030 with an electrospray ion mass spectrometer (ESI-MS) in positive ion mode. The ESI was performed with a $125 \mathrm{~V}$ fragment or and a $65 \mathrm{~V}$ skimmer. At a flow rate of $10 \mathrm{~L} / \mathrm{min}$, a nebulizer at 45 pressure, and a capillary temperature of $350 \mathrm{C}$, high-purity nitrogen (99.999 percent) was used as the drying gas. A blank of 0.1 percent formic acid was utilized in parallel. The Shimadzu CBM-20A system controller, the LC-30AD pump, the SIL-30AC autosampler with cooler and the CTO-30 column oven were used to inject a sample into the mass detector.

\section{Results}

From January 8, 2020 to January 10, 2020, we checked 3725 butchered animals during our last inspection. In 25 of the 3725 animals killed, hydatid cysts were confirmed.

\section{Isolation of protoscolices associated bacteria}

A total of $8 \%$ of the cysts were found in the lung, $16 \%$ in the liver, and $76 \%$ in both the liver and the lung. Nineteen of the 25 hydatid cyst containing animals were infected with one or more bacterial species representing a bacterial infection rate of $76 \%$. (Table 1). Thirty-one bacterial isolates were collected from hydatid cysts fluid of lung, liver or lung and liver. Interestingly, 78.9\% of the isolated bacteria were isolated from samples of bi-organs infected animals. Gram negative bacteria were found in six of the isolates, while Gram positive bacteria were found in two. Staphylococcus xylosus, Achromobacter xylosoxidans, and Pseudomonas aeruginosa have been the most prevalent bacteria detected in hydatid cysts fluid retrieved from the lungs, whereas Micrococcus spp. and E. coli were recovered from hepatic hydatid cysts fluid. Klebsiella oxytoca, Enterobacter aerogenes, Pseudomonas aeruginosa, and Enterobacter amnigenus were identified from the fluid of hydatid cysts in the lungs

and livers. Pseudomonas aeruginosa was the most commonly isolated species, with 9 isolates; other species included 6, 5, 4, 2, and 2 isolates, respectively, for K. oxytoca, E. amnigenus, E. aerogenes, A. xylosoxidans, and E. coli. Micrococcus spp. was identified from two samples of fluid collected from the liver, whereas $S$. xylosus was recovered from one hydatid cyst fluid sample collected from the lung. 
Table 1

Bacteria isolated from hydatid cysts fluid in the lungs or/and livers of sheep and goats

\begin{tabular}{|c|c|c|c|c|c|c|c|c|c|}
\hline \multirow[t]{2}{*}{ Animal } & \multirow{2}{*}{$\begin{array}{l}\text { Infected } \\
\text { organs }\end{array}$} & \multicolumn{6}{|c|}{ Gram negative bacteria } & \multicolumn{2}{|c|}{ Gram positive bacteria } \\
\hline & & $\begin{array}{l}\text { P. } \\
\text { aeruginosa }\end{array}$ & $\begin{array}{l}\text { K. } \\
\text { oxytoca }\end{array}$ & $\begin{array}{l}\text { E. } \\
\text { amnigenus }\end{array}$ & $\begin{array}{l}\text { E. } \\
\text { aerogenes }\end{array}$ & $\begin{array}{l}\text { A. } \\
\text { xylosoxidans }\end{array}$ & $\begin{array}{l}\text { E. } \\
\text { coli }\end{array}$ & $\begin{array}{l}\text { Micrococcus } \\
\text { spp. }\end{array}$ & $\begin{array}{l}\text { S. } \\
\text { xylosus }\end{array}$ \\
\hline sheep & $\begin{array}{l}\text { lung } \\
\text { and } \\
\text { liver }\end{array}$ & * & * & & * & & & & \\
\hline sheep & lung & & & & & * & & & * \\
\hline sheep & $\begin{array}{l}\text { lung } \\
\text { and } \\
\text { liver }\end{array}$ & * & & * & & & & & \\
\hline sheep & $\begin{array}{l}\text { lung } \\
\text { and } \\
\text { liver }\end{array}$ & & * & & & & & & \\
\hline goats & liver & & & & & & * & * & \\
\hline sheep & $\begin{array}{l}\text { lung } \\
\text { and } \\
\text { liver }\end{array}$ & & & * & & & & & \\
\hline sheep & $\begin{array}{l}\text { lung } \\
\text { and } \\
\text { liver }\end{array}$ & * & * & & & & & & \\
\hline sheep & lung & * & & & & * & & & \\
\hline sheep & $\begin{array}{l}\text { lung } \\
\text { and } \\
\text { liver }\end{array}$ & & & & * & & & & \\
\hline sheep & $\begin{array}{l}\text { lung } \\
\text { and } \\
\text { liver }\end{array}$ & * & & & & & & & \\
\hline sheep & liver & & & & & & & & \\
\hline sheep & $\begin{array}{l}\text { lung } \\
\text { and } \\
\text { liver }\end{array}$ & * & & & & & & & \\
\hline sheep & $\begin{array}{l}\text { lung } \\
\text { and } \\
\text { liver }\end{array}$ & & & & & & & & \\
\hline sheep & $\begin{array}{l}\text { lung } \\
\text { and } \\
\text { liver }\end{array}$ & * & & * & & & & & \\
\hline sheep & $\begin{array}{l}\text { lung } \\
\text { and } \\
\text { liver }\end{array}$ & * & & & & & & & \\
\hline sheep & $\begin{array}{l}\text { lung } \\
\text { and } \\
\text { liver }\end{array}$ & * & * & & & & & & \\
\hline sheep & $\begin{array}{l}\text { lung } \\
\text { and } \\
\text { liver }\end{array}$ & & & & & & & & \\
\hline sheep & $\begin{array}{l}\text { lung } \\
\text { and } \\
\text { liver }\end{array}$ & & & & & & & & \\
\hline
\end{tabular}




\begin{tabular}{|c|c|c|c|c|c|c|c|c|c|}
\hline \multirow[t]{2}{*}{ Animal } & \multirow{2}{*}{$\begin{array}{l}\text { Infected } \\
\text { organs }\end{array}$} & \multicolumn{6}{|c|}{ Gram negative bacteria } & \multicolumn{2}{|c|}{ Gram positive bacteria } \\
\hline & & $\begin{array}{l}\text { P. } \\
\text { aeruginosa }\end{array}$ & $\begin{array}{l}\text { K. } \\
\text { oxytoca }\end{array}$ & $\begin{array}{l}\text { E. } \\
\text { amnigenus }\end{array}$ & $\begin{array}{l}\text { E. } \\
\text { aerogenes }\end{array}$ & $\begin{array}{l}\text { A. } \\
\text { xylosoxidans }\end{array}$ & E. & $\begin{array}{l}\text { Micrococcus } \\
\text { spp. }\end{array}$ & $\begin{array}{l}\text { S. } \\
\text { xylosus }\end{array}$ \\
\hline sheep & $\begin{array}{l}\text { lung } \\
\text { and } \\
\text { liver }\end{array}$ & & & * & * & & & & \\
\hline sheep & $\begin{array}{l}\text { lung } \\
\text { and } \\
\text { liver }\end{array}$ & & & & & & & & \\
\hline sheep & $\begin{array}{l}\text { lung } \\
\text { and } \\
\text { liver }\end{array}$ & & * & & & & & & \\
\hline sheep & $\begin{array}{l}\text { lung } \\
\text { and } \\
\text { liver }\end{array}$ & & & * & & & & & \\
\hline goats & liver & & & & & & & & \\
\hline goats & liver & & & & & & * & * & \\
\hline sheep & $\begin{array}{l}\text { lung } \\
\text { and } \\
\text { liver }\end{array}$ & & * & & * & & & & \\
\hline \multicolumn{2}{|c|}{ Total isolates } & 9 & 6 & 5 & 4 & 2 & 2 & 2 & 1 \\
\hline
\end{tabular}

Treatment of protoscolices in vitro with methanolic extracts of R. graveolens, P. harmala, and C. colocynths

The hydatid cyst protocols were treated with methanolic extracts of $R$. gravelens, $P$. harmala, and $C$. colocynths for various periods of time $(1,3,6,12,18$ and 24 hours). The extract concentrations used in this study were 10, 20,30, and $40 \mathrm{mg} / \mathrm{mL}$ (Table 2 and Fig. 1a-c). When protoscolices were treated with $R$. gravelens methanol extract, the killing of protoscolices was dramatically increased. This study discovered that using different concentrations of methanol extracts from $R$. graveolens, $P$. harmala, and $C$. colocynths resulted in a significant effect (P 0.05), with mortality rates of $100 \%, 50 \%$, and $15 \%$ after treatment for periods of 1.25 hours, 24 hours, and 24 hours, respectively, and using the maximum concentration $(40 \mathrm{mg} / \mathrm{mL})$. The survivability testing findings were in line with the morphological changes and structural damages seen in protoscolices. As shown in structural and morphological investigations involving SEM, there was a positive association between the intensity of injury and the extract concentration (Figs. 2a-d). Alterations in protoscolices included loss of motility, paralysis, tegument bleb formation, contraction of the soma area, rostellar disarray and loss of hooks and microtriches. Normal protoscolices showed green fluorescence as a result of acridine orange penetrating the normal cell membrane, but apoptotic protoscolices showed orange colored apoptotic bodies occurring as a result of nuclear shrinkage, damage, and blebbing (Fig. 3). When studied under a fluorescent microscope, dead protoscolices showed red hue fluorescence due to their loss of membrane integrity. These structural and morphological changes were identical to those seen in protoscolices that had been treated with ABZ in vitro. 
Table 2

Protoscolosidal effect of various concentrations of $R$. graveolens, $C$. colocynthisand $P$. harmalamethanolicextractsand ABZ.in vitro.

\begin{tabular}{|c|c|c|c|c|c|c|c|}
\hline \multirow[t]{2}{*}{ Plant extract } & \multirow[t]{2}{*}{ Con. mg/mL } & \multicolumn{6}{|c|}{ Mortality Rate (\%) } \\
\hline & & $1 \mathrm{hr}$ & $3 \mathrm{hr}$ & $6 \mathrm{hr}$ & $12 \mathrm{hr}$ & $18 \mathrm{hr}$ & $24 \mathrm{hr}$ \\
\hline \multirow[t]{4}{*}{ R. graveolens } & 10 & $65.3 \pm 4.6$ & $87.5 \pm 0.3$ & $96.0 \pm 2.0$ & $100 \pm 0.0$ & $100 \pm 0.0$ & $100 \pm 0.0$ \\
\hline & 20 & $75 \pm 2.0$ & $97.5 \pm 1.3$ & $98.5 \pm 1.0$ & $100 \pm 0.0$ & $100 \pm 0.0$ & $100 \pm 0.0$ \\
\hline & 30 & $84.5 \pm 1.8$ & $98 \pm 1.0$ & $100 \pm 0.0$ & $100 \pm 0.0$ & $100 \pm 0.0$ & $100 \pm 0.0$ \\
\hline & 40 & $98 \pm 1.2$ & $100 \pm 0.0$ & $100 \pm 0.0$ & $100 \pm 0.0$ & $100 \pm 0.0$ & $100 \pm 0.0$ \\
\hline \multirow[t]{4}{*}{ P. harmala } & 10 & $2.9 \pm 1.5$ & $4.0 \pm 0.4$ & $7.7 \pm 1.0$ & $9.7 \pm 1.2$ & $11.6 \pm 1.4$ & $15.3 \pm 2.0$ \\
\hline & 20 & $4.8 \pm 0.9$ & $9.1 \pm 2.2$ & $18.4 \pm 1.4$ & $28.3 \pm 1.7$ & $31.5 \pm 0.8$ & $34.7 \pm 1.0$ \\
\hline & 30 & $8.4 \pm 0.6$ & $16.6 \pm 1.5$ & $22.2 \pm 2.3$ & $27.9 \pm 2.7$ & $40.3 \pm 4.7$ & $45.7 \pm 1.4$ \\
\hline & 40 & $14.5 \pm 2.3$ & $19.2 \pm 2.4$ & $26.3 \pm 3.5$ & $33.7 \pm 2.1$ & $42.7 \pm 5.6$ & $50.0 \pm 1.7$ \\
\hline \multirow[t]{4}{*}{ C. colocynths } & 10 & $2.7 \pm 0.6$ & $4.7 \pm 1.5$ & $6.0 \pm 2.6$ & $7.8 \pm 2.3$ & $9.7 \pm 2.1$ & $10.3 \pm 2.3$ \\
\hline & 20 & $1.7 \pm 0.6$ & $4.0 \pm 1.0$ & $4.3 \pm 0.6$ & $6.3 \pm 1.5$ & $8.0 \pm 1.7$ & $9.7 \pm 1.5$ \\
\hline & 30 & $4.0 \pm 1.0$ & $5.3 \pm 1.2$ & $7.3 \pm 1.5$ & $9.3 \pm 1.5$ & $10.3 \pm 1.2$ & $12.7 \pm 1.5$ \\
\hline & 40 & $5.3 \pm 0.6$ & $7.3 \pm 1.2$ & $8.3 \pm 0.6$ & $10.3 \pm 0.6$ & $12.3 \pm 1.5$ & $15.3 \pm 2.1$ \\
\hline -Ve Control & & $1.7 \pm 0.6$ & $1.7 \pm 0.6$ & $2 \pm 1.2$ & $2.5 \pm 0.6$ & $3 \pm 0.6$ & $4.5 \pm 0.0$ \\
\hline +Ve Control (ABZ) & 20 & $3 \pm 2.0$ & $9.7 \pm 1.5$ & $22.7 \pm 4.5$ & $47.5 \pm 4.6$ & $71.7 \pm 2.5$ & $96.3 \pm 3.1$ \\
\hline
\end{tabular}

\section{Antibacterial activity}

The disc diffusion method was used to test the antibacterial activity of methanolic extracts of $R$. graveolens, $P$. harmala, and $C$. colocynthis at two different concentrations. In general, all of the extracts examined had varying antibacterial activity that was dose-dependent. $R$. graveolenswas the most effective extract, followed by P. harmala and $C$. colocynthis. The gram-negative $A$. xylosoxidans strains were the most sensitive, with the largest inhibition zone (18.3 $\mathrm{mm})$. The methanolic extract of $R$. graveolens had wide antibacterial activity. All bacterial strains were inhibited by $R$. graveolens methanolic extract at both concentrations tested, with the exception of $S$. xylosus at $1 \mathrm{mg} /$ disc. Strong antibacterial activity of $R$. graveolens extract against A. xylosoxidans, E. amnigenus, S. aureus ATCC 43300, B. subtilis ATCC 6633, E. aerogenes, and B. cereus ATCC 11778 was seen at the maximum dosage tested $(2 \mathrm{mg})$, with inhibition zones ranging from 14.0 to $18.3 \mathrm{~mm}$. $R$. graveolens methanolic extract had moderate antibacterial activity against E. coli, P. aeruginosa ATCC 27853, Micrococcus spp, $S$. xylosus, $P$. aeruginosa, and $K$. oxytoca, with an inhibition zone ranging from 10.3 to $13.3 \mathrm{~mm}$ (Table 3 ). 
Table 3

Antibacterial activity of methanolic extracts of $R$. graveolens, P. harmala and $C$. colocynthis using disc diffusion method.

\begin{tabular}{|c|c|c|c|c|c|c|}
\hline \multirow[t]{3}{*}{ Bacterial species } & \multicolumn{6}{|c|}{ Zone of inhibition (mm) } \\
\hline & \multicolumn{2}{|c|}{ R. graveolens } & \multicolumn{2}{|l|}{ P. harmala } & \multicolumn{2}{|c|}{ C. colocynthis } \\
\hline & $1 \mathrm{mg} /$ disc & $2 \mathrm{mg} /$ disc & $1 \mathrm{mg} /$ disc & $2 \mathrm{mg} / \mathrm{disc}$ & $1 \mathrm{mg} /$ disc & $2 \mathrm{mg} / \mathrm{disc}$ \\
\hline \multicolumn{7}{|l|}{ Gram positive bacteria } \\
\hline Micrococcus spp. & $8.7 \pm 0.57$ & $13.0 \pm 1.0$ & $9.0 \pm 1.0$ & $11.3 \pm 0.57$ & $-v e^{\star}$ & $8.7 \pm 0.57$ \\
\hline S. xylosus & -ve & $10.3 \pm 1.5$ & -ve & -ve & -ve & $-v e$ \\
\hline S. aureus ATCC 43300 & $12.0 \pm 1.0$ & $15.4 \pm 1.2$ & $12.0 \pm 1.0$ & $14.3 \pm 1.15$ & $11.0 \pm 1.0$ & $13.3 \pm 0.58$ \\
\hline B.cereus ATCC11778 & $10.0 \pm 1.3$ & $14.0 \pm 1.0$ & $9.7 \pm 0.58$ & $13.0 \pm 1.0$ & $9.3 \pm 0.58$ & $12.4 \pm 0.55$ \\
\hline B. subtilisATCC6633 & $10.0 \pm 1.0$ & $14.7 \pm 0.58$ & $10.0 \pm 1.0$ & $13.0 \pm 1.0$ & $9.0 \pm 1.0$ & $12.3 \pm 0.58$ \\
\hline \multicolumn{7}{|l|}{ Gram negative bacteria } \\
\hline P. aeruginosa & $10.0 \pm 1.3$ & $13.0 \pm 1.0$ & $10.0 \pm 1.0$ & $12.7 \pm 0.6$ & -ve & -ve \\
\hline A. xylosoxidans & $14.0 \pm 1.5$ & $18.3 \pm 1.5$ & $0.0 \pm 0.0$ & $9.7 \pm 0.6$ & -ve & -ve \\
\hline E. coli & $10.3 \pm 1.5$ & $13.3 \pm 1.5$ & $8.7 \pm 0.57$ & $11.66 \pm 0.57$ & -ve & $-v e$ \\
\hline E. amnigenus & $11.0 \pm 1.0$ & $16.0 \pm 0.8$ & -ve & -ve & -ve & $-v e$ \\
\hline E. aerogenes & $10.7 \pm 0.6$ & $14.7 \pm 1.15$ & -ve & -ve & -ve & -ve \\
\hline K. oxytoca & $10.3 \pm 1.5$ & $12.7 \pm 2.0$ & -ve & $10.7 \pm 0.6$ & -ve & -ve \\
\hline E. coliATCC 25922 & $10.0 \pm 1.0$ & $12.4 \pm 0.55$ & $9.0 \pm 1.0$ & $11.4 \pm 0.53$ & -ve & -ve \\
\hline P. aeruginosa ATCC27853 & $9.3 \pm 0.58$ & $13.0 \pm 1.0$ & $10.3 \pm 0.58$ & $13.0 \pm 1.0$ & -ve & $-v e$ \\
\hline
\end{tabular}

S. aureus was the most susceptible strain to $P$. harmala extract, with inhibition zones of 12.0 and $14.3 \mathrm{~mm}$ at doses of 1 and 2 $\mathrm{mg} /$ disc, respectively. The inhibition zones of $P$. harmala extract against $B$. cereus ATCC $11778, B$. subtilis ATCC $6633, P$. aeruginosa ATCC 27853, P. aeruginosa, E. coliATCC 25922, Micrococcus spp, K. oxytoca, and A. xylosoxidans ranged from 13.0 to $9.7 \mathrm{~mm}$ at the highest concentration tested. Because no inhibitory zones were found, E. amnigenus, E. aerogenes, and $S$. xylosus appear to be resistant to $P$. harmala extract.

The disc diffusion method also revealed that the extract of $C$. colocynthis has antibacterial activity against gram-positive bacteria. S. aureus ATCC 43300, B. cereus ATCC11778, B. subtilis ATCC 6633, and Micrococcus spp. were inhibited by $C$. colocynthis extracts in zones ranging from 13.3 to $8.7 \mathrm{~mm}$. Against all gram negative bacteria tested, no inhibition zones were found.

Table 4 shows the MIC of $\mathrm{MeOH}$ extracts of $R$. graveolens, $P$. harmala, and $C$. colocynthisis. In general, the MIC results were consistent with the inhibitory zones seen, with $R$. graveolens being the most potent extract, followed by $P$. harmala, and then $C$. colocynthis. B. cereus ATCC 11778 was the most sensitive bacterial strain. All of the extracts studied are still more efficient against gram positive bacteria than gram negative bacteria. 
Table 4

The MIC of $\mathrm{MeOH}$ extract of $R$. graveolens, P. harmala and C. colocynthis plants on different bacterial strains $[\mathrm{mg} / \mathrm{ml}]$.

\begin{tabular}{|c|c|c|c|}
\hline & \multicolumn{3}{|l|}{$\mathrm{MIC}(\mathrm{mg} / \mathrm{mL})$} \\
\hline & R. graveolens & P. harmala & C. colocynthis \\
\hline \multicolumn{4}{|l|}{ Gram positive bacteria } \\
\hline Micrococcus spp. & 1.0 & 1.0 & 2.0 \\
\hline S. xylosus & 2.0 & $>2.0$ & $>2.0$ \\
\hline S. aureus ATCC 43300 & 0.5 & 1.0 & 2.0 \\
\hline B. cereus ATCC 11778 & 0.25 & 0.25 & 0.5 \\
\hline B. subtilisATCC 6633 & 0.5 & 0.25 & 0.5 \\
\hline \multicolumn{4}{|l|}{ Gram negative bacteria } \\
\hline P. aeruginosa & 1.0 & 1.0 & $>2.0$ \\
\hline A. xylosoxidans & 0.5 & 2.0 & $>2.0$ \\
\hline E. coli & 1.0 & 1.0 & $>2.0$ \\
\hline E. amnigenus & 1.0 & $>2.0$ & $>2.0$ \\
\hline E. aerogenes & 1.0 & $>2.0$ & $>2.0$ \\
\hline K. oxytoca & 1.0 & $>2.0$ & $>2.0$ \\
\hline E. coliATCC 25922 & 1.0 & 1.0 & $>2.0$ \\
\hline P. aeruginosa ATCC 27853 & 1.0 & 1.0 & $>2.0$ \\
\hline
\end{tabular}

R. graveolens extract had MIC values of less than $2 \mathrm{mg} / \mathrm{mL}$ against all microorganisms tested. B. cereus ATCC $11778(0.25$ $\mathrm{mg} / \mathrm{mL})$ had the lowest MIC value, followed by S. aureus ATCC43300 $(0.5 \mathrm{mg} / \mathrm{mL}), B$. subtilis ATCC $6633(0.5 \mathrm{mg} / \mathrm{mL})$, and $A$. xylosoxidans $(0.5 \mathrm{mg} / \mathrm{mL})$. The MIC value for $K$. oxytoca $(1.5 \mathrm{mg} / \mathrm{mL})$ was the highest.

P. harmala extract had MIC values of $0.25 \mathrm{mg} / \mathrm{mL}$ against B. cereus ATCC 11778 and B. subtilis ATCC 6633, respectively. P. harmala extract had MIC values of $1 \mathrm{mg} / \mathrm{mL}$ against Micrococcus spp., S. aureus ATCC 43300, E. coli, E. coli ATCC 25922, and $P$. aeruginosa ATCC 27853 , but $1.5 \mathrm{mg} / \mathrm{mL}$ against $P$. aeruginosa ATCC 27853. S. xylosus E. amnigenus, E. aerogenes, and $K$. oxytoca were resistant to $P$. harmala extract with MIC values less than $2 \mathrm{mg} / \mathrm{mL}$, according to disc diffusion technique data.

C. colocynthis extract was more efficient against gram positive bacteria than gram negative bacteria, similar to the results of the disc diffusion approach. $C$. colocynthis extract has a MIC of less than $2 \mathrm{mg} / \mathrm{mL}$ against all gram negative bacteria tested. $B$. cereus ATCC 11778 and B. subtilis ATCC 6633 had the lowest MIC values $(0.5 \mathrm{mg} / \mathrm{mL}$ and $2.0 \mathrm{mg} / \mathrm{mL}$, respectively), followed by Micrococcus spp. $(1.5 \mathrm{mg} / \mathrm{mL})$ and $S$. xylosus and $S$. aureus ATCC $43300(2.0 \mathrm{mg} / \mathrm{mL}$, respectively).

Chemical composition of R. graveolens,P. harmala and C. colocynthis using LC-MS

LC-MS was used to examine the chemical composition of methanolic extracts of $R$. graveolens, $P$. harmala aerial parts and the C. colocynthis seeds (data not shown). In the methanolic extract of the aerial portion of $R$. graveolens, a total of 26 compounds were identified. Rutin (13.7\%), quercetin (9.3\%), isoquinoline (6.9\%), methoxypsoralen (6.8\%), procyanidin (6.3\%), and Tropane (6.3\%) were the predominant components of $R$. graveolens methanolic extract (5.5 percent). In the aerial component of $P$. harmala methanolic extract, 31 compounds were identified using LCMS. The primary components were discovered as harmaline (10.6 percent), harmine (6.3 percent), and pinene (6.3 percent). Linalool (5.9\%), squalene (5.8\%), terpineol (5.5\%), 
catechin (5.4\%), limonene (5.3\%), terpinene (5.35), flavan (4.9\%), and anthraquinone (4.9\%) were found abundant in the extract (4.7\%). The methanolic extract of $C$. colocynthis seeds comprised 32 compounds. Lactic acid was found in the highest concentration (10.2\%), followed by xylitol (7.4\%), glycerol (7.2\%), proline (6.2\%), inositol (5.4\%), glucitol (5.4\%), lauric acid (5.4\%), linoleic acid (5.3\%), phytol (5.3\%), and campesterol (5.3\%).

\section{Discussion}

E. granulosus causes cystic echinococcosis, a parasitic cestode illness. It causes a medically and veterinary-important persistent infection (Ahmed et al. 2021; Zeghir-Bouteldja et al. 2009).Several previous studies found a high incidence (88 percent) of bacterial infection in hydatid cysts isolated from cattle, goats, and sheep (Hadadi, et al. 2020; Khleifat et al. 2010; Ziino et al. 2009).

ABZ had a modest effect on protoscolices, whereas $R$. graveolens extract was a highly effective protoscolicidal agent that did not require ABZ synergy. All dosages of $R$. graveolens extract $(10,20,30$, and $40 \mathrm{mg} / \mathrm{ml}$ ) revealed considerable protoscolicidal activity against protoscolices obtained from contracted sheep and goats' organs in a short period. At a dose of $40 \mathrm{mg} / \mathrm{ml}$, protoscolices perished entirely (100\%) after $3 \mathrm{hrs}$ of exposure time, whereas a control dose of $20 \mathrm{mg} / \mathrm{ml} \mathrm{ABZ} \mathrm{caused} \mathrm{almost}$ less $10 \%$ lethal effect $(3 \mathrm{hrs})$. The viability test results corroborate morphological and structural changes detected using a compound, fluorescence, and scanning electron microscopy. Tissue injury was assessed at the ultrastructural level using a scanning electron microscope (SEM). After culture in the presence of $R$. graveolens extract and ABZ, invaginated protoscolices showed evident changes, including the collapse of the soma region, disarray in the rosteller cone, damage to the scolex and sucker region and damage to the surface teguments. In comparison to the control group, the damage was decreased but still significant at the highest concentration of $C$. colocynthis extract.

In this study, the percentage of bacterial infection of hydatid cysts was 76 percent, which is consistent to other studies. Furthermore, the most common bacterial isolates were P. aeruginosa, K. oxytoca, E. amnigenus, and E. aerogenes, indicating that gram negative bacteria are the most common bacterial invaders in hydatid cysts. Gram-negative bacteria were identified from 87.1 percent of hepatic and 85.4 percent of lung hydatid cyst fluid in sheep, with E. coli and K. pneumoniae being the most common isolates, according to similar studies (Abdullah et al. 2021; Fallah et al. 2014; Khleifat et al. 2010). In contrast, $S$. aureus was recovered from hepatic hydatid cyst fluids in a recent test, demonstrating that the types of bacteria isolated from the cyst fluids are highly varied et al. 2020 ).This could be due to the infective stages ability to live in the outside environment, as well as the life cycle of Echinococcus spp., which entails tissue translocation into the intermediate host.

Despite the idea that hydatid cyst fluid is a sterile fluid, bacterial pathogens from the respiratory and gastrointestinal tract were found in high numbers in bi-organ cyst fluid samples in this study. In addition to being harmful, these isolates are naturally widespread in the environment and are part of the usual flora of warm-blooded animals. According to one theory, intermediate animals such as sheep and goats swallow bacteria-infected Echinococcus spp. eggs (Ahmed et al. 2021; Fallah et al. 2014). When these eggs reach the colon, they hatch, and the bacterially tainted oncosphere embryo penetrates the mucosa, eventually forming hydatid cysts in the liver and lungs. According to certain views, the infection may have entered by the bile duct or enterohepatic circulation. Although only to a limited extent, hydatid cysts can be infected through the bronchial tree or a hematogenous pathway (Ahmed et al. 2021; Wani et al. 2010; Ziino et al. 2009).

The current study's findings revealed that the plants studied have varying amounts of antibacterial activity. The inhibitory zone results were consistent with the MIC values for the various plant extracts. $R$. graveolens was the most effective extract, followed by $P$. harmala and $C$. colocynthis. The gram-negative $A$. xylosoxidans strains were the most sensitive, with the largest inhibition zone $(18.3 \mathrm{~mm})$. All of the bacterial strains tested were inhibited by the methanolic extract of $R$. graveolens. Only at a concentration of $2 \mathrm{mg} / \mathrm{disc}$ did $S$. xylosus demonstrate an inhibiting effect. Strong antibacterial activity of $R$. graveolens extract against A. xylosoxidans, E. amnigenus, S. aureus ATCC 43300, B. subtilis ATCC 6633, E. aerogenes and B. cereus ATCC 11778 was seen at the maximum dose tested $(2 \mathrm{mg})$, with inhibition zones ranging from 14.0 to $18.3 \mathrm{~mm}$. R. graveolens methanolic extract had moderate antibacterial activity against $E$. coli, P. aeruginosa ATCC 27853, Micrococcus spp, S. xylosus, $P$. aeruginosa, and $K$. oxytoca, with inhibition zones ranging from 10.3 to $13.3 \mathrm{~mm}$. The inhibitory zone results were consistent 
with the MIC values for $R$. graveolens extract. This demonstrates that the $R$. graveolens extract has scolocidal and bactericidal capabilities at the same time. Because these bacteria are among the most frequent pathogenic bacteria that raise the risk of secondary infection during hydatid cysts, the results of inhibition zones and MICs of the R. graveolens extract are deemed highly promising.

These findings are consistent with those of (Pavić et al. 2019), who found that $R$. graveolens extract had excellent antibacterial activity against gram-positive bacteria such Staphylococcus aureus, Streptococcus pyogenes, Listeria monocytogenes and Bacillus subtilis. Molnar et al. (Molnar et al. 2018), found that $R$. graveolensm ethanolic extracts had good antibacterial activity against $E$. coli, $P$. aeruginosa, $B$. subtilis, and $S$. aureus, which is consistent with our findings. Rutin, quercetin, isoquinoline, tropane, procyanidin, and hydroxyl benzoic acids are phenolic chemicals found in the aerial portions of $R$. graveolens that have antibacterial and antifungal properties (Wolters and Eilert 1981). Acridone alkaloids and coumarin, phytochemical substances found in $R$. graveolens aerial portions, showed the strongest antibacterial action against Gram-positive and Gram-negative bacteria (Ivanova et al. 2005). Flavonoids such as rutinand quercetin, phenolic compounds, alkaloids and terpenoides isolated from R. graveolens showed antibacterial activity against Staphylococcus aureus and Bacillus subtilis (Amabye, 2015), the high antimicrobial activity of this plant may be due to presence of these compounds. The MIC values of $R$. graveolens extract against all tested bacteria were less than $2 \mathrm{mg} / \mathrm{mL}$, with $B$. cereus and $K$. oxytoca having the lowest $(0.25 \mathrm{mg} / \mathrm{mL})$ and highest $(1.5 \mathrm{mg} / \mathrm{mL})$ MIC values, respectively.

$P$. harmala extract was more efficient against gram positive bacteria than gram negative bacteria in this investigation. The $P$. harmala extract had moderate narrow spectrum antibacterial activity against Gram negative bacteria ( Sohrabi, et al. 2018; ElZayat et al. 2021). P. harmala chloroform extract has broad spectrum antibacterial activity against $P$. aeruginosa and $S$. aureuS, according to another study, with a MIC value of $1.56 \mathrm{ug} / \mathrm{mL}$. (Hadadi et al. 2020). The antibacterial activity of a flavonoid-rich extract of $P$. harmala leaves was outstanding against $E$. coli, but there was no antibacterial activity against $S$. aureus (Fatma et al. 2016). The methanolic extract of $P$. harmala aerial parts was shown to be high in beta-carboline, harmaline, and harmine in this study. The beta-carboline molecules are one of $P$. harmala's most potent components (Moloudizargari et al. 2013). Harmane, harmine, harmaline, and harmalol have been found to be bacteriostatic against E. coli, Proteus vulgaris, $S$. aureus, and $B$. subtilis (Nenaah 2010). In vivo and in vitro, these core chemicals may be responsible for antibacterial, antiparasitic, and other biological actions (Doskaliyev et al. 2021). Other chemicals identified from $P$. harmala extracts, such as catechin, apigenin, rutin, anthraquinone, and flavan, may have diverse biological actions, as demonstrated in various investigations. (Allaq et al. 2021; Darabpour et al. 2011; Elansary et al. 2020; Mounira et al. 2021).Most bacteria isolated from hydatid cysts were resistant to $P$. harmala extract at high concentrations (MIC $>2 \mathrm{mg} / \mathrm{ml}$ ), while MIC results for different ATCC bacteria ranged between 0.25 and $1.5 \mathrm{mg} / \mathrm{mL}$. The varying quantities of antibiotics provided to afflicted sheep may have contributed to the high resistance of bacteria isolated from hydatid cysts.

C. colocynthis seed extract has been shown to have weak antibacterial activity. However, against gram positive bacteria, $C$. colocynthis seed extract was more efficient than against gram negative bacteria. It was mentioned that all gram negative bacteria, as well as S. aureus was resistant to C. colocynthis seed extracts (Bourhia et al. 2021). Gram-positive and Gramnegative bacteria were inhibited by $C$. colocynthis extracted using high polarity solvents such as water and acetone. Cucurbitacin $\mathrm{B}, \mathrm{E}$, and $\mathrm{I}$, among the most potent components of $C$. colocynthis seed, have been shown to have antibacterial action against Staphylococcus aureus, Bacillus cereus, and K. pneumonia (Ali et al. 2013). Cucurbitacin E has also been shown to have antibacterial properties against M. tuberculosis H37Rvat (Bourhia et al. 2020). The biological activity of plant extracts is dependent on the solvent and extraction method used, and the antimicrobial effectiveness of plant extracts is dependent on the active substances, selected bacterial strains, and plant parts tested,so antimicrobial activity may differ from one bacterium gram negative to another gram positive (Qaralleh et al. 2019). This low activity could be due to acquired resistance through mutations, or to infected animals' failure to respond to all applicable treatments. The findings of variances in antibacterial outcomes, could be related to differences in plant collecting time or phytochemical concentration during season growth (Kumar et al. 2006; Esiyok et al. 2004).

\section{Conclusion}

Page $12 / 18$ 
The current study demonstrated the antibacterial activity of $R$. graveolens, $P$. harmala and $C$. colocynthisagainst pathogenic bacteria isolated from hydatid cysts. The results of this study provide evidence to use and develop naturally occurring agents such as $R$. graveolensand P. harmala aerial part extracts as antibacterial agents. Scolocidal and antibacterial properties of methanolic extracts of $R$. graveolensmay have the ability to reduce the in vivo appearance of secondary infection in hydatid cysts. This can be applied to protecting and treating humans as well as animals. However, further investigation is required, including studying their toxicity effects of these extracts

\section{References}

1. Abdullah, M., Ali, I., Haleem, K. S., Rehman, A. U., Qayyum, S., Niaz, Z., ... Sultana, N. (2021). Molecular and biochemical characterization of echinococcus spp. In hydatid cyst fluid collected from human and livestock in northern khyber pakhtunkhwa and gilgit baltistan. J Anim Plant Sci, 31(5): 1293-1301

2. Ahmed, A. B., Ras, R., Mahmoud, A. F., El-Ghazaly, E., Widmer, G., Dahshan, H., \& Elsohaby, I. (2021). Prevalence and bacterial isolation from hydatid cysts in dromedary camels (Camelus dromedarius) slaughtered at Sharkia abattoirs, Egypt. J Parasit Dis 45(1): 236-243.

3. Ahmed, C. N., Hamad, K. K., \& Qadir, F. A. (2019). Haemonchus contortus as a model in assessing activity of Citrullus colocynthis fruit extract to control benzimidazole-resistant parasitic nematodes. ZANCO J Pure Appl Sci 31(5), 61-70.

4. Aitken, M. M., Jones, P. W., Hall, G. A., Hughes, D. L., \& Collis, K. A. (1978). Effects of experimental Salmonella dublin infection in cattle given Fasciola hepatica thirteen weeks previously. J Comp Pathol 88(1), 75-84.

5. Al-Arabi, F. Y., Mehdi, M. A. H., Farooqui, M., \& Pradhan, V. (2019). The effect of Aloe vera extracts on the viability of Echinococcus granulosus protoscolices. Int Res J Pharm 10(4), 184-189.

6. Al-Asoufi, A., Khlaifat, A., Tarawneh, A. A., Alsharafa, K., Al-Limoun, M., \& Khleifat, K. (2017). Bacterial Quality of Urinary Tract Infections in Diabetic and Non Diabetics of the Population of Ma'an Province, Jordan. Pak J Biol Sci 20(4), 179-188.

7. Al-Shuneigat, J. M., Al-Tarawneh, I. N., Al-Qudah, M. A., Al-Sarayreh, S. A., Al-Saraireh, Y. M., \& Alsharafa, K. Y. (2015). The chemical composition and the antibacterial properties of Ruta graveolens $L$. essential oil grown in Northern Jordan. Jordan J Biological Sci 8(2), 139-143.

8. Ali, A. A., Alian, M. A., \& Elmahi, H. A. (2013). Phytochemical analysis of some chemical metabolites of Colocynth plant [Citrullus colocynthis L.] and its activities as antimicrobial and antiplasmidial. J Basic Appl Sci Res 3(5): 228-236.

9. Ali, S. A., Dawood, K. A., \& Al-Oumashi, G. B. (2012). Hydatidosis of cattle with secondary bacterial invaders. Kufa J Vet Med Sci 3(2).

10. Allaq, A. A., Sidik, N. J., Abdul-Aziz, A., Alkamil, A. M. A., Elengoe, A., Yahya, E. B., \& Abdulsamad, M. A. (2021).

Epidemiological studies of the novel Coronavirus (COVID-19) in Libya. Pak J Biol Sci 18(1-2)), 7-16.

11. Alzoreky, N. S., \& Nakahara, K. (2003). Antibacterial activity of extracts from some edible plants commonly consumed in Asia. Int. J. Food Microbiol 80(3), 223-230.

12. Amabye TG, Shalkh TM (2015) Phytochemical Screening and Evaluation of Antibacterial Activity of Ruta graveolens L. - A Medicinal Plant Grown around Mekelle,Tigray, Ethiopia. Nat Prod Chem Res 3: 195. doi:10.4172/2329-6836.1000195

13. Asgarpanah, J., \& Khoshkam, R. (2012). Phytochemistry and pharmacological properties of Ruta graveolens L. J Med Plants Res 6(23), 3942-3949.

14. Blanton, R. E., Wachira, T. M., Zeyhle, E. E., Njoroge, E. M., Magambo, J. K., \& Schantz, P. M. (1998). Oxfendazole treatment for cystic hydatid disease in naturally infected animals. Antimicrobial Agents and Chemotherapy, 42(3), 601-605.

15. Boes, J., \& Helwigh, A. B. (2000). Animal models of intestinal nematode infections of humans. Parasitology, 121(S1), S97S111.

16. Bourhia, M., Bouothmany, K., Bakrim, H., Hadrach, S., Salamatullah, A. M., Alzahrani, A., ... Laglaoui, A. (2021). Chemical Profiling, Antioxidant, Antiproliferative, and Antibacterial Potentials of Chemically Characterized Extract of Citrullus colocynthis L. Seeds. Separations, 8(8), 114.

Page 13/18 
17. Bourhia, M., Messaoudi, M., Bakrim, H., Mothana, R. A., Sddiqui, N. A., Almarfadi, O. M., ... Benbacer, L. (2020). Citrullus colocynthis (L.) Schrad: Chemical characterization, scavenging and cytotoxic activities. Open Chemistry, 18(1), 986-994.

18. Carvalho, L. S. A. de, Queiroz, L. S., Alves Junior, I. J., Almeida, A. das C., Coimbra, E. S., de Faria Pinto, P., ... Da Silva Filho, A. A. (2019). In vitro schistosomicidal activity of the alkaloid-rich fraction from Ruta graveolens L.(Rutaceae) and its characterization by UPLC-QTOF-MS. Evidence-Based Complementary and Alternative Medicine, 2019.

19. Darabpour, E., Bavi, A. P., Motamedi, H., \& Nejad, S. M. S. (2011). Antibacterial activity of different parts of Peganum harmala L. growing in Iran against multi-drug resistant bacteria. EXCLI Journal, 10, 252.

20. De Queiroz, A. C., Dias, T. de L. M. F., Da Matta, C. B. B., Cavalcante Silva, L. H. A., de Araújo-Júnior, J. X., Araújo, G. B. de, ... Alexandre-Moreira, M. S. (2014). Antileishmanial activity of medicinal plants used in endemic areas in northeastern Brazil. Evidence-Based Complementary and Alternative Medicine, 2014.

21. Dhakad, P. K., Sharma, P. K., \& Kumar, S. (2017). A review on phytochemical studies and biological potential of Citrullus colocynthis (L.) Schrad (Cucurbitaceae). J Bioeng Biosci, 5(4): 55-64.

22. dos Santos, P. R. D., de Lima Moreira, D., Guimarães, E. F., \& Kaplan, M. A. C. (2001). Essential oil analysis of 10 Piperaceae species from the Brazilian Atlantic forest. Phytochemistry, 58(4), 547-551.

23. Doskaliyev, A., Seidakhmetova, R., Tutai, D. S., Goldaeva, K., Surov, V. K., \& Adekenov, S. M. (2021). Alkaloids of Peganum harmala L. and their Pharmacological Activity. Open Access Maced J Med Sci 9(A), 766-775.

24. Durgadevi, P. S. K. S., Saravanan, A., \& Uma, S. (2019). Antioxidant potential and antitumour activities of Nendran banana peels in breast cancer cell line. Indian J Pharm Sci 81(3), 464-473.

25. El-Zayat, M. M., Eraqi, M. M., Alfaiz, F. A., \& Elshaer, M. M. (2021). Antibacterial and antioxidant potential of some Egyptian medicinal plants used in traditional medicine. J King Saud Univ Sci 33(5), 101466.

26. Elansary, H. O., Szopa, A., Kubica, P., Ekiert, H., El-Ansary, D. O., A Al-Mana, F., \& Mahmoud, E. A. (2020). Polyphenol content and biological activities of Ruta graveolens L. and Artemisia abrotanum L. in northern Saudi Arabia. Processes, 8(5), 531.

27. Esiyok, D., Otles, S., \& Akcicek, E. (2004). Herbs as a food source in Turkey. Asian Pac J Cancer Prev 5(3), 334-339.

28. Fallah, M., Kavand, A., \& Mashouf, R. Y. (2014). Infected hydatid cysts bacteria in slaughtered livestock and their effects on protoscoleces degeneration. Jundishapur J Microbiol 7(6).

29. Fatma, B., Fatiha, M., Elattafia, B., \& Noureddine, D. (2016). Phytochemical and antimicrobial study of the seeds and leaves of Peganum harmala L. against urinary tract infection pathogens. Asian Pac J Trop Dis 6(10), 822-826.

30. Friedman, N. D., Kaye, K. S., Stout, J. E., McGarry, S. A., Trivette, S. L., Briggs, J. P., ... Walton, A. L. (2002). Health careassociated bloodstream infections in adults: a reason to change the accepted definition of community-acquired infections. Ann. Intern. Med 137(10), 791-797.

31. Hadadi, Z., Nematzadeh, G. A., \& Ghahari, S. (2020). A study on the antioxidant and antimicrobial activities in the chloroformic and methanolic extracts of 6 important medicinal plants collected from North of Iran. BMC Chemistry, 14(1), $1-11$.

32. Hijjawi, N. S., Al-Radaideh, A. M., Rababah, E. M., Al-Qaoud, K. M., \& Bani-Hani, K. E. (2018). Cystic echinococcosis in Jordan: a review of causative species, previous studies, serological and radiological diagnosis. Acta Tropica 179: 10-16.

33. Ivanova, A., Mikhova, B., Najdenski, H., Tsvetkova, I., \& Kostova, I. (2005). Antimicrobial and cytotoxic activity of Ruta graveolens. Fitoterapia, 76(3-4), 344-347.

34. Jahed Khaniki, G. R., Kia, E. B., \& Raei, M. (2013). Liver condemnation and economic losses due to parasitic infections in slaughtered animals in Iran. J Parasit Dis 37(2): 240-244.

35. Khleifat, K., Abboud, M., Al-Shamayleh, W., Jiries, A., \& Tarawneh, K. (2006). Effect of chlorination treatment on gram negative bacterial composition of recycled wastewater. Pak J Biol Sci 9: 1660-1668.

36. Khleifat, K. M., Halasah, R. A., Tarawneh, K. A., Halasah, Z., Shawabkeh, R., \& Wedyan, M. A. (2010). Biodegradation of linear alkylbenzene sulfonate by Burkholderia sp.: Effect of some growth conditions. Int J Agr Biol 12:17-25.

37. Khleifat, K. M., Tarawneh, K. A., Ali Wedyan, M., Al-Tarawneh, A. A., \& Al Sharafa, K. (2008). Growth kinetics and toxicity of Enterobacter cloacae grown on linear alkylbenzene sulfonate as sole carbon source. Currt Microbiol 57(4): 364-370.

Page 14/18 
38. Kumar, V. P., Chauhan, N. S., Padh, H., \& Rajani, M. (2006). Search for antibacterial and antifungal agents from selected Indian medicinal plants. J Ethnopharm 107(2): 182-188.

39. Malekifard, F., \& Keramati, F. (2018). Susceptibility of Protoscoleces of Hydatid Cyst to Various Concentrations of Oak Gall (Quercus infectoria Olivier) Extract at Different Exposure Times In Vitro. Zahedan. J. Res. Med. Sci 20(5).

40. Mamedov, N. A., Pasdaran, A., \& Mamadalieva, N. Z. M. (2018). Pharmacological studies of Syrian rue (Peganum harmala L., Zygophyllaceae). Int J Second Metab 5(1): 1-6.

41. Moazeni, M., Larki, S., Saharkhiz, M. J., Oryan, A., Ansary Lari, M., \& Mootabi Alavi, A. (2014). In vivo study of the efficacy of the aromatic water of Zataria multiflora on hydatid cysts. Antimicrob Agents Chemother 58(10): 6003-6008.

42. Moazeni, M., Saadaty Ardakani, Z. S., Saharkhiz, M. J., Jalaei, J., Khademolhoseini, A. A., Shams Esfand Abad, S., \& Mootabi Alavi, A. (2017). In vitro ovicidal activity of Peganum harmala seeds extract on the eggs of Fasciola hepatica. $J$ Paras Dis 41(2): 467-472.

43. Molnar, M., Tomić, M., \& Pavić, V. (2018). Coumarinyl thiosemicarbazides as antimicrobial agents. Pharm Chem J 51(12): 1078-1081.

44. Moloudizargari, M., Mikaili, P., Aghajanshakeri, S., Asghari, M. H., \& Shayegh, J. (2013). Pharmacological and therapeutic effects of Peganum harmala and its main alkaloids. Pharmacogn Rev 7(14): 199.

45. Monteiro, D. U., Azevedo, M. I., Weiblen, C., Botton, S. D. A., Funk, N. L., Da Silva, C. D. B., ... DE LA RUE, M. L. (2017). In vitro and ex vivo activity of Melaleuca alternifolia against protoscoleces of Echinococcus ortleppi. Parasitology, 144(2): 214219.

46. Mounira, K., Farah, R., Rachida, B., \& Halima, A. (2021). Preliminary Phytochemical Screening, Quantification of phenolic compounds, of Plant Extract from Chenopodium quinoa. Alger. j. biosciences 2(01): 42-45.

47. Nabaei, M., Mesbah, A. R., Ghavami, H., Saeidinia, A., \& Keihanian, F. (2014). Effects of Ruta graveolens extract on Histopathologic changes in mice livers. Int J Pharm Res Scholars 3(2): 675-680.

48. Najim, T. M., Shahooth, M. A., \& khamees Abed, S. (2020). Isolation Of Bacteria Associated With Hepatic Hydatid Cyst Of Iraqi Sheep. Eur J Mol Clin Med 7(11), 972-976.

49. Nasrieh, M. A., Abdel-Hafez, S. K., Kamhawi, S. A., Craig, P. S., \& Schantz, P. M. (2003). Cystic echinococcosis in Jordan: socioeconomic evaluation and risk factors. Parasitol Res 90(6): 456-466.

50. Nenaah, G. (2010). Antibacterial and antifungal activities of (beta)-carboline alkaloids of Peganum harmala ( $L$ ) seeds and their combination effects. Fitoterapia 81(7): 779-782.

51. Niroumand, M. C., Farzaei, M. H., \& Amin, G. (2015). Medicinal properties of Peganum harmala L. in traditional Iranian medicine and modern phytotherapy: a review. J Tradit Chin Med 35(1): 104-109.

52. Oran, S A, \& Al-Eisawi, D. M. (1998). Check-list of medicinal plants in Jordan. Dirasat, 25(2), 84-112.

53. Oran, S. A. (2014). The status of medicinal plants in Jordan. J. Agric. Sci. Technol. A, 4(6A).

54. Patel, M. H., Patel, A. M., Patel, S. M., Ninama, G. L., Patel, K. R., \& Lavingia, B. C. (2011). Antifungal susceptibility testing to determine mic of amphotericine $b$, fluconazole and ketoconazole against ocular fungal infection. Nat $\mathrm{J}$ Comm Med, 2 : 302-305.

55. Pathak, S., Multani, A. S., Banerji, P., \& Banerji, P. (2003). Ruta 6 selectively induces cell death in brain cancer cells but proliferation in normal peripheral blood lymphocytes: A novel treatment for human brain cancer. Int J Oncol 23(4): 975982.

56. Pavić, V., Flačer, D., Jakovljević, M., Molnar, M., \& Jokić, S. (2019). Assessment of total phenolic content, in vitro antioxidant and antibacterial activity of Ruta graveolens L. extracts obtained by choline chloride based natural deep eutectic solvents. Plants, 8(3): 69.

57. Qaralleh, H., Khleifat, K. M., Al-Limoun, M. O., Alzedaneen, F. Y., \& Al-Tawarah, N. (2019). Antibacterial and synergistic effect of biosynthesized silver nanoparticles using the fungi Tritirachium oryzae W5H with essential oil of Centaurea damascena to enhance conventional antibiotics activity. Adv Nat Sci Nanosci. Nanotechnol 10(2), 025016. 
58. Rezaee, M., \& Hajighasemi, F. (2019). Sensitivity of hematopoietic malignant cells to Peganum harmala seed extract in vitro. J Basic Clin Physiol Pharmacol 7(1): 21-26.

59. Romero, C. D., Chopin, S. F., Buck, G., Martinez, E., Garcia, M., \& Bixby, L. (2005). Antibacterial properties of common herbal remedies of the southwest. J Ethnopharm 99(2): 253-257.

60. Smyth, J. D., \& Barrett, N. J. (1980). Procedures for testing the viability of human hydatid cysts following surgical removal, especially after chemotherapy. Trans R Soc Trop Med Hyg 74(5): 649-652.

61. Sohrabi, R., Moghaddam, M. T., Maghsood, A. H., Matini, M., Moradkhani, S., \& Fallah, M. (2018). Scolicidal effects of barberry (Berberis vulgaris), wild rue seed (Peganom harmala) and shirazian thyme (Zataria multiflora) extracts on protoscolices of hydatid cysts. Zahedan. J. Res. Med. Sci 20(12).

62. Uma, C., \& Sekar, K. G. (2014). Phytochemical analysis of a folklore medicinal plant Citrullus colocynthis L (bitter apple). Int J Pharmacogn. Phytochem Res 2(6).

63. Wang, B., Jiang, Y., Wang, Z., Li, F., Xing, G., Peng, X., ... Lv, H. (2015). Arsenic trioxide negatively affects Echinococcus granulosus. Antimicrob Agents Chemother 59(11): 6946-6951.

64. Wani, I., Bhat, Y., Khan, N., Mir, F., Nanda, S., \& Shah, O. J. (2010). Concomitant rupture of hydatid cyst of liver in hepatic duct and gallbladder: case report. Gastroenterol Res 3(4): 175.

65. Wink, M. (2012). Medicinal plants: a source of anti-parasitic secondary metabolites. Molecules 17(11): 12771-12791.

66. Wolters, B., \& Eilert, U. (1981). Antimicrobial substances in callus cultures of Ruta graveolens. Planta Medica 43(10): 166174.

67. Yones, D. A., Taher, G. A., \& Ibraheim, Z. Z. (2011). In vitro effects of some herbs used in Egyptian traditional medicine on viability of protoscolices of hydatid cysts. Korean J Parasitol 49(3), 255.

68. Zeghir-Bouteldja, R., Amri, M., Aitaissa, S., Bouaziz, S., Mezioug, D., \& Touil-Boukoffa, C. (2009). In vitro study of nitric oxide metabolites effects on human hydatid of Echinococcus granulosus. J Parasitol Res 2009.

69. Ziino, G., Giuffrida, A., Panebianco, A., \& Bilei, S. (2009). Bacteria isolated from 25 hydatid cysts in sheep, cattle and goats. Vet Rec 165(8), 234-236.

\section{Figures}




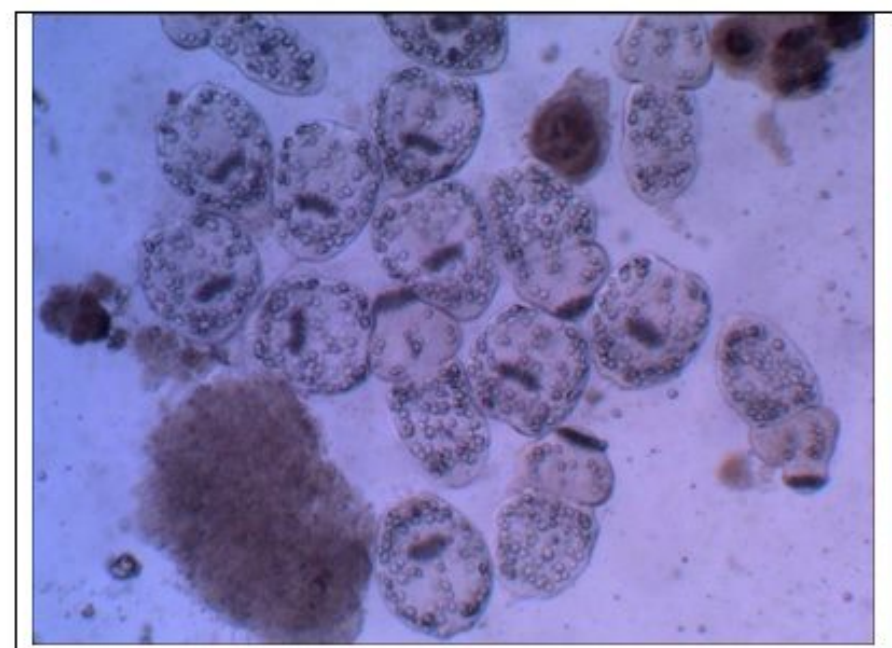

A

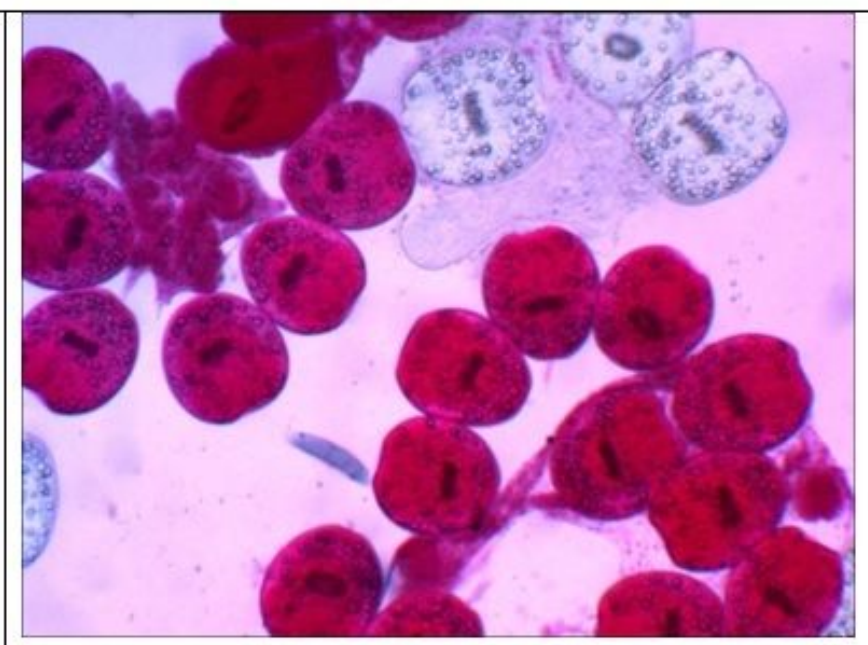

B

C

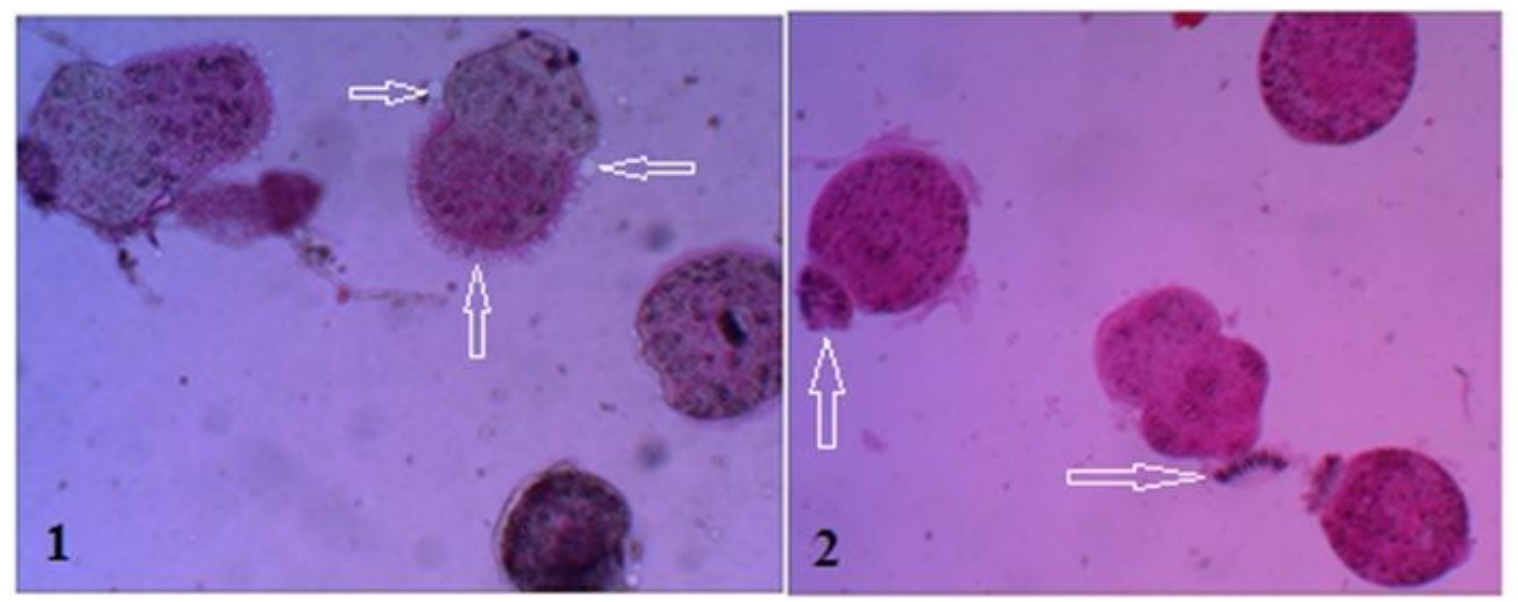

Figure 1

Images of living, dead, and partially dead E. granulosus protoscolices following staining with 0.1 percent eosin; (a), protoscolices untreated with plant extract. (b), effect of $20 \mathrm{mg} / \mathrm{mL} \mathrm{ABZ}$ on protoscolices after 24 hours of exposure (c), total mortality of protoscolices after 1.25 hours ( 75 minutes) of exposure to $40 \mathrm{mg} / \mathrm{mL} R$. graveolensextract1. Blebs formation in tegument, 2. Rostellar disorganization and loss of hooks and microtriches. (Total magnification 100X) 


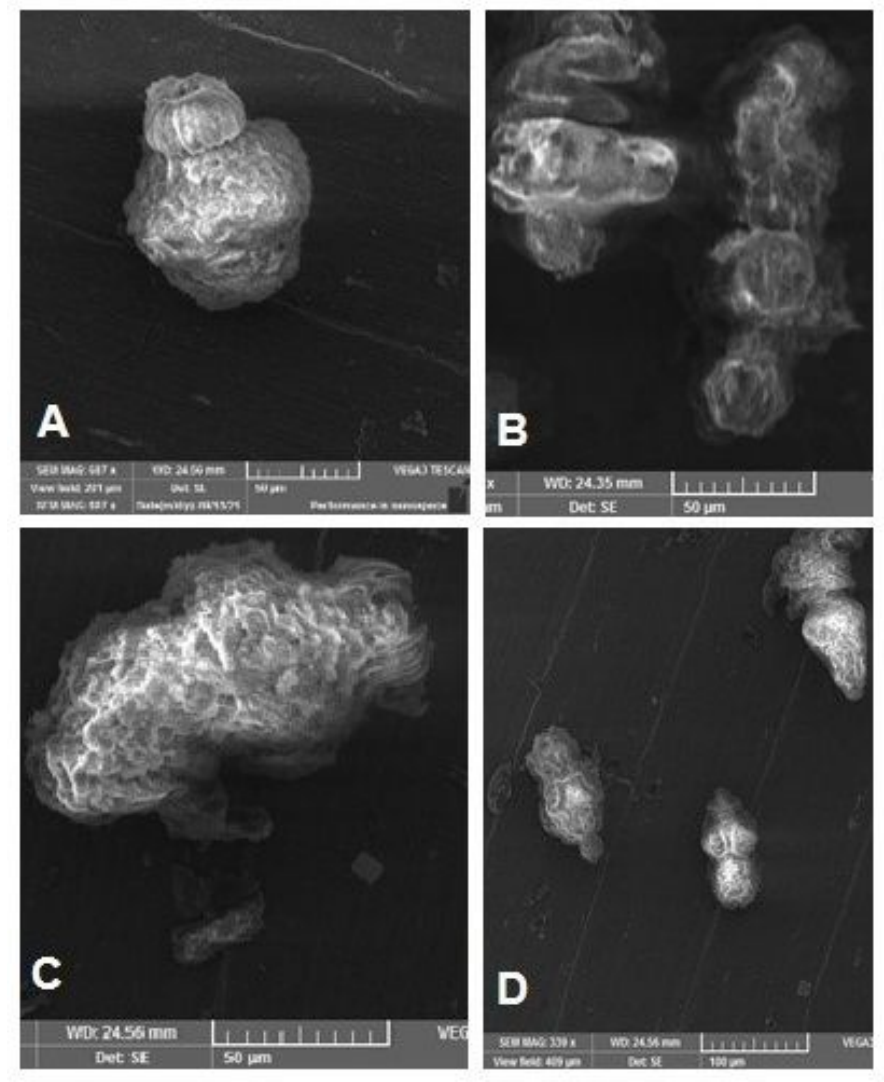

\section{Figure 2}

The ultrastructural damages observed with scanning electron microscopy when treated with $R$. graveolensextract. (A):Evaginated control protoscolex, (B):Invaginated protoscolices, clearly altered after culture in the presence of $R$. graveolensextract, collapse of soma region, disorganization in the rosteller cone is visible with damage in scolex and sucker region. (C): Loosening of hooks, disorganization of hooks was also observed at rosteller cone (D): Collapse of the soma region, shedding of microtriches of the scolex region and damage at the surface teguments is also observed. (Magnification $A, B, C$ 686X, D, 340X).

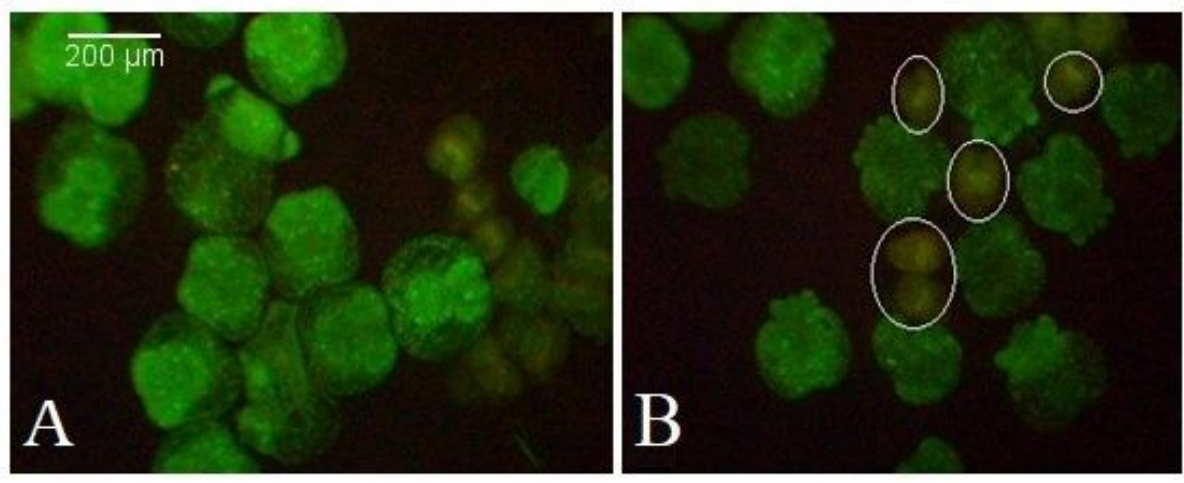

\section{Figure 3}

Viable and deadprotoscolices stained by acridine orange and ethidium bromide (a): Viable protoscolices appeared in bright green color and (b):Dead protoscolices with red color when treated with R. graveolens. 